\title{
Antimicrobials from Wild Strains of Lactic Acid Bacteria for Commercial Applications
}

\author{
S. Priyadarshini ${ }^{1}$, R. Subhashini ${ }^{1 *}$, T. Uma Maheswari ${ }^{2}$ and M.L. Mini ${ }^{1}$ \\ ${ }^{1}$ Department of Agricultural Microbiology, Agricultural College and Research Institute, Tamil \\ Nadu Agricultural University, Madurai - 625104, Tamil Nadu, India \\ ${ }^{2}$ Department of Food Science and Nutrition, Community Science College and Research \\ Institute, Tamil Nadu Agricultural University, Madurai-625104, Tamil Nadu., India \\ *Corresponding author
}

Keywords

Antimicrobials, Wild strains, Lactic acid bacteria,

Commercial applications

\section{Article Info}

Accepted:

10 November 2020

Available Online:

10 December 2020

\section{A B S T R A C T}

This study aims to screen wild strains of lactic acid bacteria for antimicrobial activity to control the food borne pathogens as natural biopreservatives to reduce the ill effects of synthetic preservatives. The antimicrobial efficacy of 14 Lactic acid bacteria (LAB) isolated from fermented food samples were tested. Nearly 19 food borne pathogens were isolated from various spoiled food samples and were used as test organisms. The LAB cultures were characterized by Gram staining, catalase test, carbohydrate fermentation test, temperature tolerance, $\mathrm{pH}$ tolerance, antibiotic sensitivity and lysozyme tolerance. Biochemical analysis like exopolysaccharides production, titrable acidity, MR-VP and esculin hydrolysis were also done. LAB isolates were tested for their antimicrobial activity against 19 food borne pathogenic test organisms. Out of 14 isolates, only 5 LAB cultures exhibited antimicrobial activity by forming inhibition zone against pathogens. The zone of inhibition was recorded maximum for CS $\left(1.33 \mathrm{~cm}^{2}\right)$ and CT $\left(1.13 \mathrm{~cm}^{2}\right)$ isolates. The LAB strains showing maximum antibacterial activity were identified as Streptococcus thermophillus and Lactobacillus coryniformis respectively by $16 \mathrm{~S}$ rRNA sequencing. This study was resulted in identification of LAB isolates from natural fermented foods for antimicrobial activity. The antimicrobial compounds may be of future interest which can be characterized and applied for biopreservation of foods.

\section{Introduction}

Food safety and food hygiene is the most important concern towards the public health caused by food contamination and food-borne diseases. In addition, ill-effects of chemical preservatives, the demand for natural food preservatives has reached its peak in recent years (Gyawali and Ibrahim, 2014). Lactic acid bacteria (LAB) have the ability to ferment food and possess higher nutritional values. Fermentation of foods enhance taste, flavour and texture of food and also exert antimicrobial activity by inhibiting the proliferation of pathogenic and spoilage microorganisms. Thus LAB can be used as a 
natural food preservative (Indira et al., 2011). The antimicrobial activity exerted by the LAB is due to the production of active metabolites like organic acids, hydrogen peroxide, diacetyl, carbon di oxide, bacteriocins and bacteriocin like inhibitory substances (BLIS) which enhance the safety and extends the shelf life of food (Aymerich et al., 2000; Favaro et al., 2015). Hence this study aims at screening and isolating the LAB from 8 different fermented food sources and to select the best isolated culture which exhibits strong antimicrobial activity against food pathogens. Thus these strains or their formulations with best antimicrobial activity can be further used for commercial application as biopreservatives.

\section{Materials and Methods}

\section{Isolation and selection of lab strains}

Lactic Acid Bacteria were isolated from fermented food samples viz., cumbu gruel, milk fermented by chilli, cold rice, neera, mango pickle, palmyrah fruit, fermented finger millet and sauerkraut. The samples were serially diluted $\left(10^{-2}\right.$ and $\left.10^{-3}\right)$ and plated using spread plate technique in de Man Rogosa and Sharpe (MRS) agar media and incubated for 48 to 72 hours at $28 \pm 2^{0} \mathrm{C}$. Well isolated single colonies from each samples were further purified and preserved.

\section{Gram reaction}

Purified LAB isolates were examined for their morphological structure and Gram staining to confirm the identity of the isolated lactic acid bacterial cultures.

\section{Catalase test}

Lactic acid bacterial isolates were tested for the production of catalase enzyme using 3\% of hydrogen peroxide. The cultures were spotted over MRS agar plates and incubated for $24 \mathrm{~h}$. Hydrogen peroxide was flooded over the spotted cultures on the plates. Catalase positive was indicated by the formation of gas bubbles over the culture and

\section{Methyl red test}

LAB cultures were inoculated in test tubes containing $5 \mathrm{ml}$ of MRVP broth and they were incubated for $48 \mathrm{~h}$. To each tube 5 drops of methyl red indicator was added and observed for colour change. Formation of red colour indicates positive result and colour change from red to yellow indicates negative result.

\section{Voges-Proskauer test}

LAB cultures were inoculated in test tube containing $5 \mathrm{ml}$ of MRVP broth and they were incubated for $48 \mathrm{~h}$. To each tube 12 drops of alpha napthol solution and 2-3 drops of $40 \%$ potassium hydroxide were added. The tubes were kept under shaking for 30seconds and exposed to air for 15-30mins. Colour changes from crimson to ruby pink indicate positive result.

\section{Sensitivity to Antibiotics}

Antibiotic sensitivity of isolates were tested against amikacin $(30 \mu \mathrm{g})$, ciprofloxacin $(5 \mu \mathrm{g})$, gentamicin $(10 \mu \mathrm{g})$, ceftazidine $(30 \mu \mathrm{g})$, cefepime $(30 \mu \mathrm{g}), \quad$ cefoxitin(30 $\mu \mathrm{g})$, cefoxatime $(30 \mu \mathrm{g})$ and ceftriaxone $(30 \mu \mathrm{g})$ by antibiotic disc assay. Formation of inhibition zone was observed and measured after $48 \mathrm{~h}$ of incubation.

\section{Carbohydrate fermentation test}

Fermentative ability of lactic acid bacterial cultures for various carbohydrates like glucose, sucrose, lactose, mannitol and malic acid were tested. The culture tubes with fermentation broth were added with specific 
carbohydrate at $1 \%$ level with inverted durham tube for detection of gas production. Phenol red was added as $\mathrm{pH}$ indicator which turns from red to yellow upon reduction in $\mathrm{pH}$ due to acid production.

\section{Determination of titrable acidity}

Acidity was measured by titrating $5 \mathrm{ml}$ of 24 $h$ old culture broth against $0.1 \mathrm{~N} \mathrm{NaOH}$ using phenolphthalein as indicator. Titration was done till the appearance of pink colour, and the titrable acidity in terms of lactic acid was determined using the formula given below (Sadler et al., 2010; Adeyemo et al., 2018).

Titrable acidity $\%=\frac{\mathrm{V}_{1} \times \mathrm{N} \text { x Eq.wt x } 100}{\mathrm{~V}_{2} \times 1000}$

Where,

$\mathrm{V}_{1}=$ volume of titrant

$\mathrm{N}=$ Normality of titrant

Eq.wt $=$ equivalent weight of acid

$\mathrm{V}_{2}=$ volume of sample

\section{Determintion of $\mathrm{pH}$ tolerance}

The LAB cultures were tested for acid tolerance by inoculating in MRS broth with different $\mathrm{pH}$ viz., 1,3 and 5, adjusted using 0.1 $\mathrm{N} \mathrm{NaOH}$. Growth was measured after an incubation period of $72 \mathrm{~h}$ at $650 \mathrm{~nm}$.

\section{Determination of temperature tolerance}

LAB cultures were inoculated in MRS broth and incubated at temperatures viz., $60^{\circ} \mathrm{C}$ and $70^{\circ} \mathrm{C}$ for $10 \mathrm{mins}$ and plated. Growth of cultures was measured after $72 \mathrm{~h}$.

\section{Determination of exopolysaccharides production}

Log cultures of isolates were centrifuged at $5000 \mathrm{rpm}$ for $10 \mathrm{~min}$ and supernatant was collected. In order to precipitate the EPS, $1 \mathrm{ml}$ of $90 \%$ ethanol was added to $0.5 \mathrm{ml}$ supernatant and stored overnight at $4{ }^{\circ} \mathrm{C}$.

The mixture was centrifuged at $8000 \mathrm{rpm}$ for $10 \mathrm{~min}$ and the precipitates were suspended in distilled water and filtered. To $0.1 \mathrm{ml}$ of filtrate $2 \mathrm{ml}$ of distilled water, $6 \%$ phenol and $5 \mathrm{ml}$ of $95 \%$ sulphuric acid were added. After $10 \mathrm{~min}$ absorbance was measured at $490 \mathrm{~nm}$ (Chunlei et al., 2014).

\section{Determination of lysozyme tolerance}

Agar well diffusion method was used to test the lysozyme tolerance of LAB isolates. LAB cultures were swabbed and wells were made on the culture swabbed agar plate. Lysozyme of concentration 1000ppm and 500 ppm was added to the wells and the culture growth was observed.

\section{Esculin hydrolysis test}

The bile esculin agar media was plated and the LAB cultures were spotted over the media and incubated for $48 \mathrm{~h}$. Formation of dark blue colour indicates the positive result for hydrolysis of esculin.

\section{Isolation of pathogenic test cultures}

The standard pathogenic organisms viz., Staphylococcus aureus, Pseudomonas aeruginosa and E.coli were obtained from department of Food Science and Nutrition, CSC and RI, Madurai. Also 16 more bacterial pathogens were isolated from potato(PTB), papaya(PYTB), apple (AOB), goat intestine(MSL,MPS and MWSB,), hen intestine (CWRB, CSG, CYB, CP, CSL and CSB) and fish wastes (FSB,FOB,FSL and FP) and characterised based on their morphology. LAB cultures were tested against totally 19 bacterial pathogens for antimicrobial activity. 


\section{Antimicrobial assay}

Agar well diffusion method was used for testing the antimicrobial activity. Test pathogens were seeded into the Muller Hinton Agar (MHA) media and allowed to solidify. Using cork borer wells were made onto the seeded agar plate. Cell free supernatant $48 \mathrm{~h}$ old $\mathrm{LAB}$ cultures were added to the wells. The plates were incubated at $37^{\circ} \mathrm{C}$ for $48 \mathrm{~h}$ and the inhibition zone was measured.

\section{Sequencing of 16S rRNA gene}

$\mathrm{LAB}$ isolates found positive for antimicrobial activity against test pathogens were characterized by $16 \mathrm{~S}$ rRNA gene sequencing using the universal primers 27F (5'- AGA GTT TGA TCM TGG CTC AG-3') and 1492R (5'- CGG TTA CCT TGT TAC GAC TT-3'). DNA was extracted from the selected two isolates and PCR amplification was done. The PCR products were custom sequenced by Eurofins Genomics India Pvt. Ltd., Bengaluru, India. BLAST tools available through the NIH (http://www.ncbi.nlm.nih. gov/gov/blast/Blast.cgi) were used to find out the similarity of DNA sequences (http://www. ncbi.nlm.nih.gov/gov/blast) and LAB culture was identified.

\section{Results and Discussion}

\section{Isolation and purification}

A total of $14 \mathrm{LAB}$ cultures were isolated from the fermented food samples and characterized based on their morphology and biochemical tests. The isolated LAB cultures were named as cumbu gruel (CS and CT), milk fermented by chilli (CD), cold rice (CR), neera (NS and NT), mango pickle (MP), palmyrah fruit $(\mathrm{PAL})$, fermented finger millet $(\mathrm{FM}(\mathrm{F}) \mathrm{T}$,
$\mathrm{FM}(\mathrm{F}) \mathrm{O}, \quad \mathrm{FM}(\mathrm{FD}) \mathrm{T}$ and $\mathrm{FM}(\mathrm{FD}) \mathrm{S})$ and sauerkraut (SKS and SKT) (Plate.1).

About $231 \mathrm{LAB}$ strains were isolated from home fermented foods and studied for their antimicrobial activity (Ren et al., 2018), from neera (Somashekaraiah et al., 2019), from fermented fish peda (Putra et al., 2018), from dairy products (El- Ghaish et al., 2017) and from fresh fruits and vegetables (Linares Morales et al., 2020).

\section{Characterization of the isolates}

All the cultures were found to be Gram positive and they were either rod and cocci shaped. In catalase test except 4 cultures viz., FM(F)O, MP, SKS and NS, all the other isolates showed negative results by not producing any gas bubbles on addition of hydrogen peroxide. All the cultures except MP were positive lysozyme tolerance test and showed growth. All the cultures except NT and SKS showed growth at temperature $60^{\circ} \mathrm{C}$ and $70^{\circ} \mathrm{C}$ and thus were observed to be highly thermo tolerant (Table 1). Tolerance to acidity was tested at $\mathrm{pH} \mathrm{1,3}$ and 5. All the isolates were observed to be acid tolerant with maximum OD recorded as $0.496,0.864$ and 1.829 exhibited by NS, FM(F)T and $\mathrm{FM}(\mathrm{FD}) \mathrm{S}$ at $\mathrm{pH} 1,3$ and 5 respectively (Table 4). Among the $14 \mathrm{LAB}$ isolates 4 isolates viz., $\mathrm{FM}(\mathrm{F}) \mathrm{O}, \mathrm{CD}, \mathrm{FM}(\mathrm{FD}) \mathrm{T}$ and $\mathrm{FM}(\mathrm{FD}) \mathrm{S}$ were sensitive to the tested antibiotics (Table 3; Plate.2). Indira et al., (2011) has done the antibiotic resistance test for $\mathrm{LAB}$ isolates against 10 antibiotics. Li et al., (2015) has demonstrated the temperature tolerance and acid tolerance of 59 LAB cultures isolated from corn stover silage producing antimicrobials and found the cultures were thermo tolerant and active at $\mathrm{pH}$ range of 2-6. 
Table.1 Gram staining, biochemical characterization and temperature tolerance

\begin{tabular}{|c|c|c|c|c|c|c|c|c|}
\hline \multirow[t]{2}{*}{$\begin{array}{c}\text { LAB } \\
\text { isolates }\end{array}$} & \multirow[t]{2}{*}{$\begin{array}{c}\text { Gram } \\
\text { Staining }\end{array}$} & \multirow[t]{2}{*}{ Catalase } & \multicolumn{2}{|c|}{ MRVP } & \multirow[t]{2}{*}{$\begin{array}{l}\text { Lysozyme } \\
\text { Tolerance }\end{array}$} & \multicolumn{2}{|c|}{$\begin{array}{l}\text { Temperature } \\
\text { Tolerance } \\
\text { (10min) }\end{array}$} & \multirow[t]{2}{*}{$\begin{array}{l}\text { Esculin } \\
\text { hydrolysis }\end{array}$} \\
\hline & & & MR & VP & & $60^{\circ} \mathrm{C}$ & $70^{\circ} \mathrm{C}$ & \\
\hline CS & + & - & + & - & + & + & + & - \\
\hline CT & + & - & + & - & + & + & + & + \\
\hline CD & + & - & + & - & + & + & + & + \\
\hline CR & + & - & + & - & + & + & + & - \\
\hline NS & + & + & + & - & + & + & + & - \\
\hline NT & + & - & + & - & + & - & - & + \\
\hline $\mathbf{F M}(\mathbf{F}) \mathbf{T}$ & + & - & + & - & + & + & + & - \\
\hline FM(F)O & + & + & + & - & + & + & + & - \\
\hline FM(FD)T & + & - & + & - & + & + & + & + \\
\hline FM(FD)S & + & - & + & - & + & + & + & + \\
\hline MP & + & + & + & - & - & + & + & - \\
\hline PAL & + & - & + & - & + & + & + & - \\
\hline SKS & + & + & + & - & + & - & - & - \\
\hline SKT & + & - & + & - & + & + & + & + \\
\hline
\end{tabular}

Table.2 Carbohydrate fermentation test

\begin{tabular}{|c|c|c|c|c|c|c|c|c|c|c|}
\hline \multirow{2}{*}{ LAB } & \multicolumn{2}{|c}{ Glucose } & \multicolumn{2}{c}{ Sucrose } & \multicolumn{2}{c|}{ Lactose } & \multicolumn{2}{c|}{ Mannitol } & \multicolumn{2}{c|}{ Maleic acid } \\
Isolates & Gas & Growth & Gas & Growth & Gas & Growth & Gas & growth & Gas & Growth \\
\hline CS & - & + & - & + & + & + & - & + & - & + \\
\hline CT & - & + & - & + & + & + & + & + & - & + \\
\hline CD & - & + & - & + & + & + & - & + & - & + \\
\hline CR & - & + & - & + & + & + & - & + & - & + \\
\hline NS & + & + & - & + & + & + & - & + & - & + \\
\hline NT & - & + & - & + & + & + & - & + & - & + \\
\hline FM(F)T & - & + & - & + & + & + & - & + & - & + \\
\hline FM(F)O & - & + & + & + & + & + & - & + & - & + \\
\hline FM(FD)T & - & + & - & + & + & + & - & + & - & + \\
\hline FM(FD)S & + & + & + & + & + & + & - & + & - & + \\
\hline MP & - & + & - & + & + & + & - & + & - & + \\
\hline PAL & - & + & - & + & + & + & - & + & - & + \\
\hline SKS & + & + & + & + & + & + & - & + & - & + \\
\hline SKT & - & + & - & + & + & + & - & + & - & + \\
\hline
\end{tabular}


Table.3 Antibiotic sensitivity test

\begin{tabular}{|c|c|c|c|c|c|c|c|c|}
\hline $\begin{array}{c}\text { LAB } \\
\text { cultures }\end{array}$ & $\begin{array}{c}\text { Amikacin } \\
(30 \mu \mathrm{g})\end{array}$ & $\begin{array}{c}\text { Ciprofloxacin } \\
(5 \mu \mathrm{g})\end{array}$ & $\begin{array}{c}\text { Gentamicin } \\
(10 \mu \mathrm{g})\end{array}$ & $\begin{array}{c}\text { Ceftazidime } \\
(30 \mu \mathrm{g})\end{array}$ & $\begin{array}{c}\text { Cefepime } \\
(30 \mu \mathrm{g})\end{array}$ & $\begin{array}{c}\text { Cefoxitin } \\
(30 \mu \mathrm{g})\end{array}$ & $\begin{array}{c}\text { Cefoxatime } \\
(30 \mu \mathrm{g})\end{array}$ & $\begin{array}{c}\text { Ceftriaxone } \\
(30 \mu \mathrm{g})\end{array}$ \\
\hline CS & - & - & + & - & - & - & - & - \\
\hline CT & - & - & - & - & - & - & - & - \\
\hline CD & - & + & + & - & - & - & - & - \\
\hline CR & - & - & - & - & - & - & - & - \\
\hline NS & - & - & - & - & - & - & - & - \\
\hline NT & - & - & - & - & - & - & - & - \\
\hline FM(F)T & - & - & - & - & - & - & - & - \\
\hline FM(F)O & - & - & - & - & - & - & - & - \\
\hline FM(FD) & - & - & - & - & - & - & - & - \\
T & - & - & - & - & - & - & - & - \\
\hline FM(FD) & - & - & - & - & - & - & - & - \\
\hline T & - & - & - & - & - & - & - \\
\hline SMD & - & - & - & - & - & - & - & - \\
\hline MP & - & - & - & - & - & - & - \\
\hline PAL & - & - & - & - & - & - & - \\
\hline SKS & - & - & - & - & - & - \\
\hline SKT & - & - & - & - & - & - \\
\hline
\end{tabular}

Table.4 Acid tolerance, exopolysaccharides production and titrable acidity

\begin{tabular}{|c|c|c|c|c|c|}
\hline \multirow{2}{*}{$\begin{array}{c}\text { LAB } \\
\text { cultures }\end{array}$} & \multicolumn{3}{|c|}{$\begin{array}{c}\mathrm{pH} \text { tolerance OD value } \\
(650 \mathrm{~nm})\end{array}$} & $\begin{array}{c}\text { Exopolysaccharides } \\
\text { OD value (490nm) }\end{array}$ & $\begin{array}{c}\text { Titrable acidity } \\
\text { (Lactic acid) } \\
\text { (\%) }\end{array}$ \\
\cline { 2 - 5 } CS & $\mathrm{pH} \mathrm{1}$ & $\mathrm{pH} \mathrm{3}$ & $\mathrm{pH} \mathrm{5}$ & 0.02 & 0.576 \\
\hline CT & 0.021 & 0.087 & 0.147 & 0.066 & 0.558 \\
\hline CD & 0.023 & 0.119 & 0.557 & 0.088 & 0.414 \\
\hline CR & 0.007 & 0.065 & 0.636 & 0.060 & 0.198 \\
\hline NS & 0.496 & 0.068 & 0.843 & 0.010 & 0.126 \\
\hline NT & 0.091 & 0.108 & 0.303 & 0.104 & 0.396 \\
\hline FM(F)T & 0.055 & 0.864 & 0.656 & 0.052 & 0.270 \\
\hline FM(F)O & 0.011 & 0.048 & 0.004 & 0.114 & 0.522 \\
\hline FM(FD)T & 0.016 & 0.064 & 0.528 & 0.070 & 0.270 \\
\hline FM(FD)S & 0.004 & 0.069 & 1.829 & 0.118 & 0.216 \\
\hline MP & 0.007 & 0.709 & 0.635 & 0.020 & 0.324 \\
\hline PAL & 0.006 & 0.051 & 0.625 & 0.121 & 0.180 \\
\hline SKS & 0.008 & 0.037 & 1.720 & 0.109 & 0.432 \\
\hline SKT & 0.045 & 0.071 & 0.068 & 0.064 & \\
\hline
\end{tabular}


Table.5 Antimicrobial assay

\begin{tabular}{|c|c|c|}
\hline Lab culture & Pathogen & Area of inhibitory zone $\left(\mathrm{cm}^{2}\right)$ \\
\hline CS & $\begin{array}{l}\text { Staphylococcus aureus } \\
\text { MSL } \\
\text { E.Coli } \\
\text { PYTB } \\
\text { FSB } \\
\text { FOB }\end{array}$ & $\begin{array}{c}0.126 \\
0.196 \\
0.196 \\
0.332 \\
1.33 \\
0.112\end{array}$ \\
\hline CT & $\begin{array}{l}\text { Staphylococcus aureus } \\
\text { MSL } \\
\text { E.Coli } \\
\text { FSB } \\
\text { FOB }\end{array}$ & $\begin{array}{c}0.096 \\
0.384 \\
0.126 \\
1.13 \\
0.10\end{array}$ \\
\hline CR & $\begin{array}{l}\text { Staphylococcus aureus } \\
\text { MWSB } \\
\text { FOB }\end{array}$ & $\begin{array}{l}0.283 \\
0.096 \\
0.097\end{array}$ \\
\hline CD & Staphylococcus aureus & 0.237 \\
\hline FM(FD) T & FSB & 0.708 \\
\hline
\end{tabular}

Plate.1 Purified LAB culture
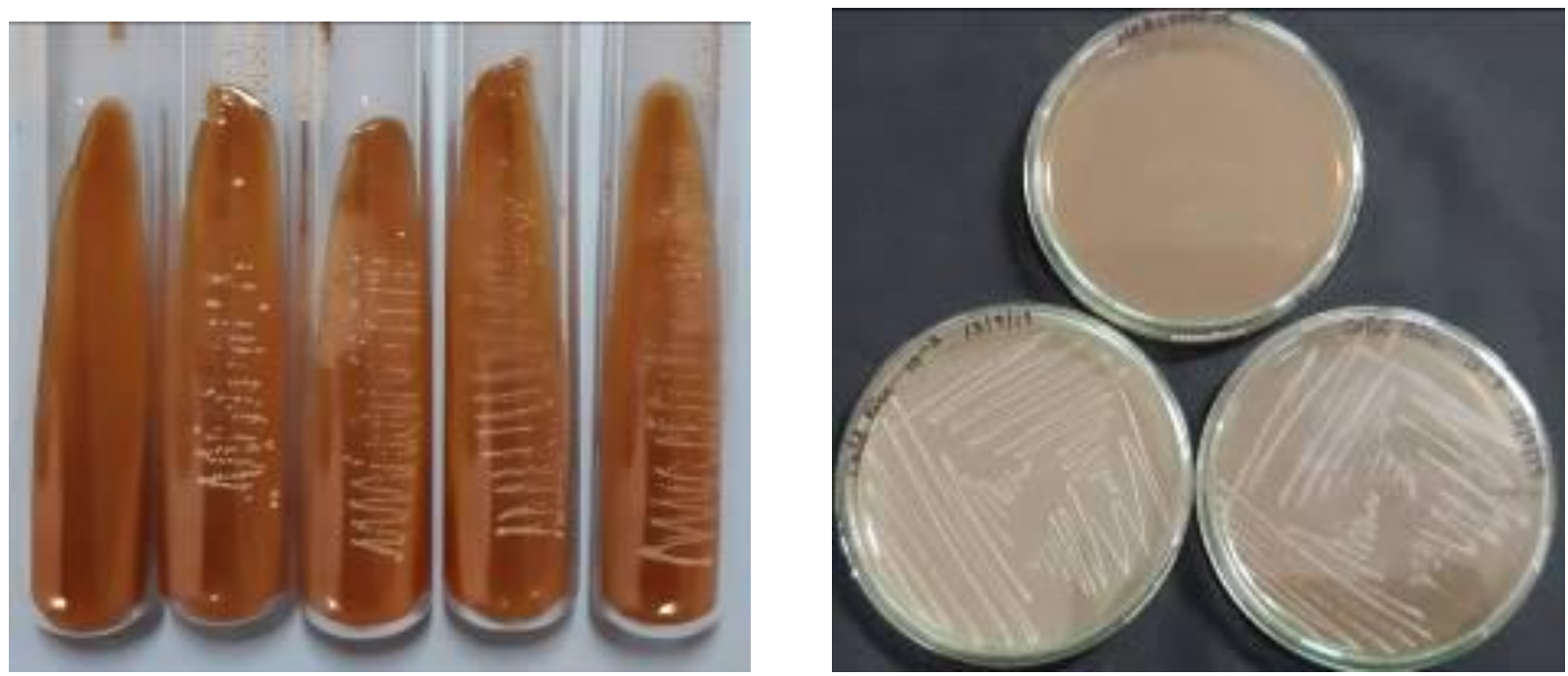
Plate. 2 carbohydrate fermentation and antibiotic sensitivity test
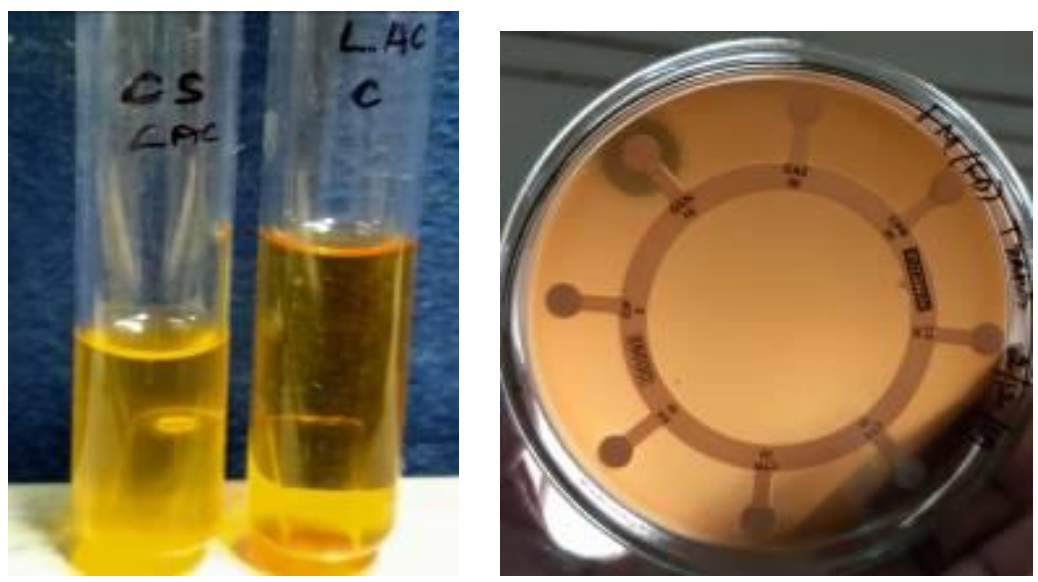

Plate. 3 Antimicrobial assay of LAB isolates

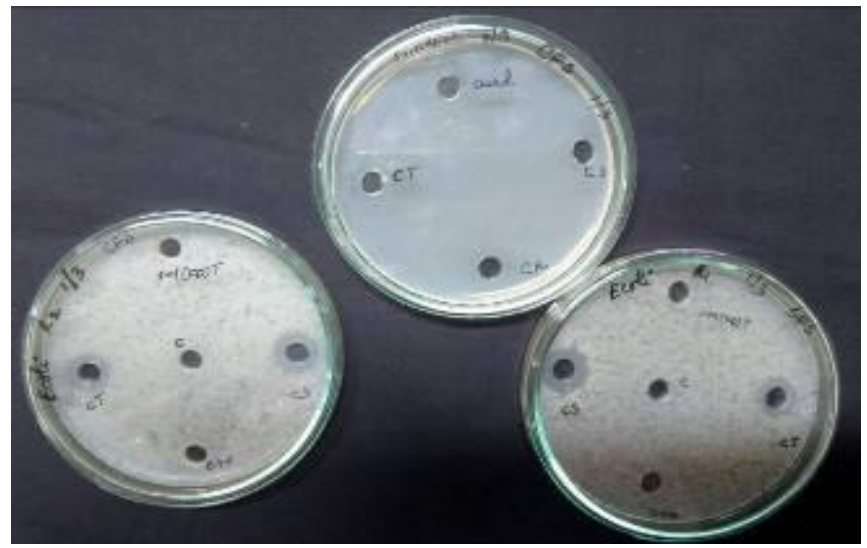

Plate.4 Gel amplification of $16 \mathrm{~S}$ rRNA gene

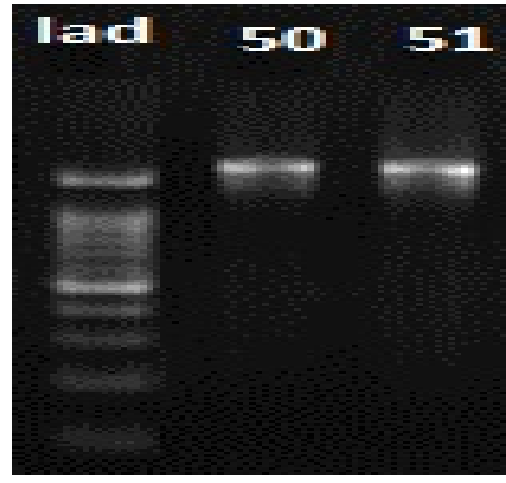




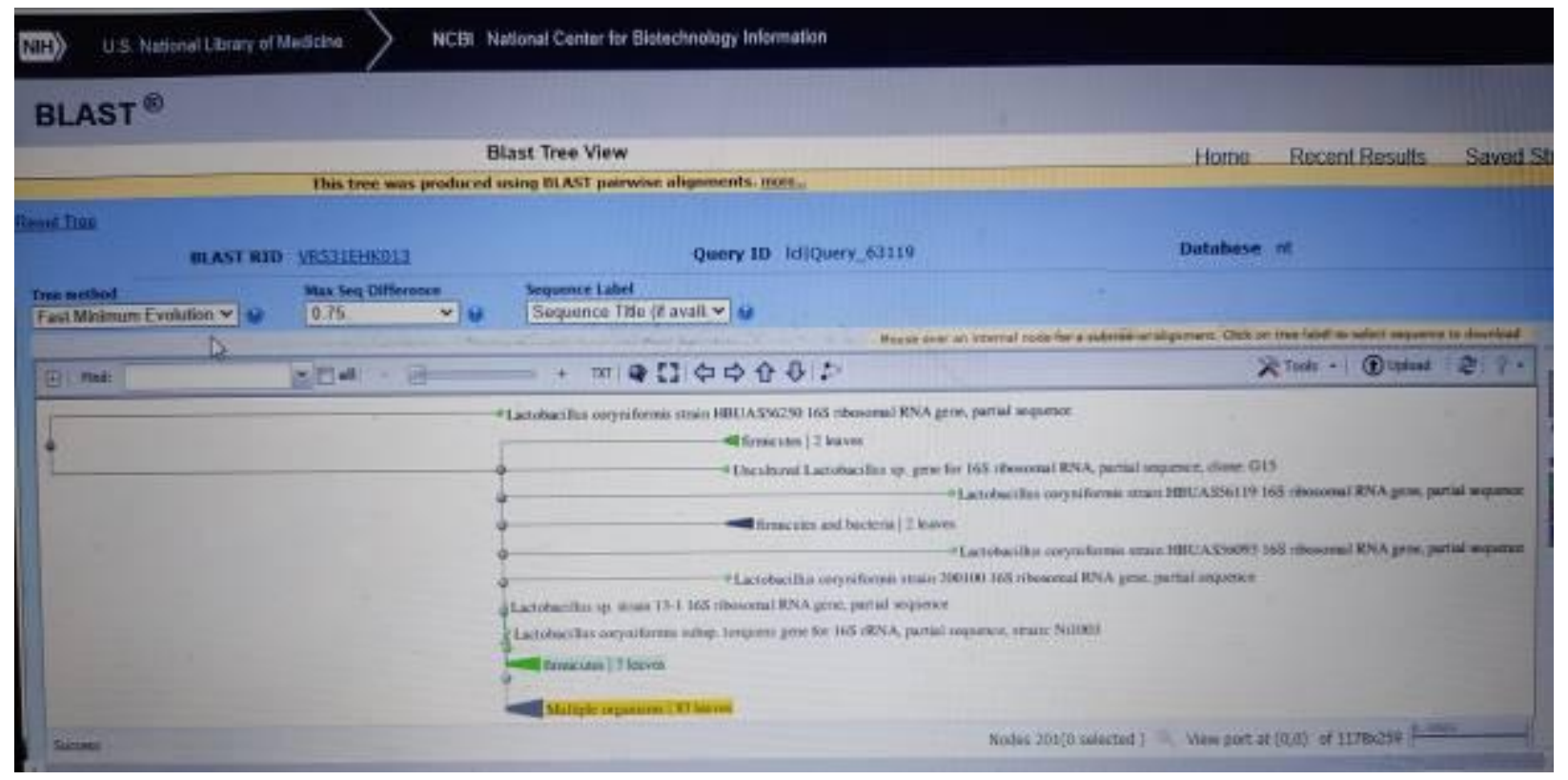

Plate.6 CS BLAST tree of Streptococcus thermophillus



\section{Biochemical tests}

The result of MR-VP test showed positive MR and negative VP reaction for all isolates.
The results of carbohydrates fermentation test is given in table 2 (Plate 2). All the cultures exhibited growth for all the tested sugars with varied gas production. Among the LAB 
isolates titrable acidity was maximum in CS culture $(0.576 \%)$ and minimum in NS isolate $(0.126 \%)$. PAL culture recorded highest exopolysaccharide production (0.121) and NS culture recorded lowest exopolysaccharides production (0.010) (Table 4). Esculin was hydrolysed by 5 isolates viz., CT, CD, NT, FM(FD)T and FM(FD)S with dark blue colouration (Table 1). Kabuki et al., (2007) tested Streptococcus thermophilus SBT1277 for esculin hydrolysi, and recorded the strain had not hydrolysed esculin. Chunlei et al., (2014) has isolated 11 LAB cultures from inner mongolian traditional yoghurt and screened them for exopolysaccharide production and the highest range recorder is $539.9 \mathrm{mg} / \mathrm{L}$.

\section{Antimicrobial activity}

Antimicrobial activity of 14 LAB cultures were investigated, where only 5 cultures viz., CS, CT, CR, CD and FM(FD)S exhibited antagonistic effect against 7 food pathogens tested out of 19 pathogens. CS and CT cultures exhibited the maximum inhibition zone of $1.33 \mathrm{~cm}^{2}$ and $1.13 \mathrm{~cm}^{2}$ respectively against FSB (Table 5; Plate 3). Dung and Phong (2011) had studied 46 LAB cultures for their antimicrobial activity and concluded that 23 strains exhibited high antimicrobial activity where 7 of them showed strong effect with inhibition zone upto $10 \mathrm{~mm}$. Thu et al., (2017) has tested 16 LAB cultures against Bacillus subtilis and all cultures possessed antimicrobial property.

\section{S rRNA sequencing}

Among the isolated Lactic Acid Bacteria CS and CT exhibited strong antimicrobial activity against wide range of food borne pathogens. Hence the 2 cultures were identified based on 16SrRNA sequencing. BLAST was run which revealed the CS culture as Streptococcus thermophiles with $93.79 \%$ similarity and CT culture as Lactobacillus coryniformis with 99.33\% similarity (Plate.4; Plate.5; Plate.6)

\section{References}

Adeyemo, S. M., Agun, T. F., and Ogunlusi, E. D. (2018). Antimicrobial Activity of Lactic Acid Bacteria Isolated from 'Pupuru': An African Fermented Staple against Food Borne-Pathogens. J Mol Biol Biotech, 3(1), 5.

Aymerich MT, Garriga M, Monfort JM, Nes I, Hugas M (2000). Bacteriocinproducing lactobacilli in Spanishstyle fermented sausages: Characterization of bacteriocins. Food Microbiol., 17: 3345.

Chun-lei, Z., Jia-qi, L., Hai-tao, G., Jie, W., and Ri-hua, X. (2014). Selection of exopolysaccharide-producing lactic acid bacteria isolates from Inner Mongolian traditional yoghurt. Mljekarstvo: casopis za unaprjeđenje proizvodnje $i$ prerade mlijeka, 64(4), 254-260.

Dung, N.T.P. and Phong, H.X., 2011. Optimal conditions for bacteriocin production by lactic acid bacteria using cheap medium of tofu sour liquid and brewer's grains. The 4th International Conference on Fermentation Technology for Value Added Agricultural Products. Khon Kaen, Thailand, p.116.

El Ghaish, S., Khalifa, M., and Elmahdy, A. (2017). Antimicrobial impact for Lactococcus lactis subsp. lactis A15 and Enterococcus faecium A15 isolated from some traditional Egyptian dairy products on some pathogenic bacteria. Journal of Food Biochemistry, 41(1), e12279.

Favaro, L., Penna, A. L. B., and Todorov, S. D. (2015). Bacteriocinogenic LAB from cheeses-application in biopreservation? Trends in food science and technology, 41(1), 37-48.

Gyawali, R., and Ibrahim, S. A. (2014). 
Natural products as antimicrobial agents. Food control, 46, 412-429.

Indira, K., Jayalakshmi, S., Gopalakrishnan, A., and Srinivasan, M. (2011). Biopreservative potential of marine Lactobacillus spp. African Journal of Microbiology Research, 5(16), 22872296.

Kabuki, T., Uenishi, H., Watanabe, M., Seto, Y., and Nakajima, H. (2007). Characterization of a bacteriocin, Thermophilin 1277, produced by Streptococcus thermophilus SBT1277. Journal of applied microbiology, 102(4), 971-980.

Li, D., Ni, K., Pang, H., Wang, Y., Cai, Y., and Jin, Q. (2015). Identification and antimicrobial activity detection of lactic acid bacteria isolated from corn stover silage. Asian-Australasian journal of animal sciences, 28(5), 620.

Linares-Morales, J. R., Cuellar-Nevárez, G. E., Rivera-Chavira, B. E., GutiérrezMéndez, N., Pérez-Vega, S. B., and Nevárez-Moorillón, G. V. (2020). Selection of Lactic Acid Bacteria Isolated from Fresh Fruits and Vegetables Based on Their Antimicrobial and Enzymatic Activities. Foods, 9(10), 1399.
Putra, T. F., Suprapto, H., Tjahjaningsih, W., and Pramono, H. (2018, April). The antagonistic activity of lactic acid bacteria isolated from peda, an Indonesian traditional fermented fish. In IOP Conference Series: Earth and Environmental Science.

Ren, D., Zhu, J., Gong, S., Liu, H., and Yu, H. (2018). Antimicrobial characteristics of lactic acid bacteria isolated from homemade fermented foods. BioMed research international, 2018.

Sadler, G. D., and Murphy, P.A. (2010). pH and titrable acidity. In Food analysis (pp.219-238). Springer, Boston, MA.

Somashekaraiah, R., Shruthi, B., Deepthi, B. V., and Sreenivasa, M. Y. (2019). Probiotic properties of lactic acid bacteria isolated from neera: A naturally fermenting coconut palm nectar. Frontiers in Microbiology, 10.

Thu, H. N. N., Long, B. H. D., Phong, H. X., Zendo, T., Sonomoto, K., and Dung, N. T. P. (2017). Selection of thermotolerant lactic acid bacteria producing high antibacterial activity and production of biomas from tofu sour liquid. Can Tho University Journal of Science, 7, 51-57.

\section{How to cite this article:}

Priyadarshini, S., R. Subhashini, T. Uma Maheswari and Mini, M.L. 2020. Antimicrobials from Wild Strains of Lactic Acid Bacteria for Commercial Applications. Int.J.Curr.Microbiol.App.Sci. 9(12): 984-994. doi: https://doi.org/10.20546/ijcmas.2020.912.119 